\section{Commentary: Cardiothoracic surgery and coronavirus disease 2019 (COVID-19): A surge of collective strength}

\author{
Jason J. Han, MD, and Pavan Atluri, MD
}

The word "quarantine" comes from the Italian quaranta, which means "forty." Before people understood the nature of the adversary, 40 days was a duration chosen for scriptural reasons in the context of purification. ${ }^{1}$ Today, we find ourselves in a quarantine once more, as the world grapples with the devastating, and still rising, tolls of the coronavirus disease 2019 (COVID-19) pandemic. However, although the language has stayed the same, our approach toward precise, systematic, and evidencebased therapy, especially in the field of cardiothoracic surgery, has since grown immeasurably. There now exist leadership, intellect, ethics, and infrastructure to respond to the pandemic regionally, nationally, and internationally. $^{2-4}$ The manuscript by Bakaeen and colleagues ${ }^{5}$ in this issue of the Journal is the epitome of this transformation and deserves our attention.

The manuscript outlines how the pandemic has affected the world at large and our field, such as the drastic reduction in procedural volume and re-allocation of resources, both material and human. It also highlights the conducive overlap between the pandemic and the domain of cardiothoracic surgery, namely our expertise in physiology, critical care, as well as initiation and management of mechanical circulatory support platforms. This information does not come as a surprise to us at this stage of the pandemic. Rather, the key wisdom of this manuscript at this juncture is in recognizing that what we do not know, instead of what we already

\footnotetext{
From the Division of Cardiovascular Surgery, Department of Surgery, University of Pennsylvania, Philadelphia, Pa.

Disclosures: The authors reported no conflicts of interest.

The Journal policy requires editors and reviewers to disclose conflicts of interest and to decline handling or reviewing manuscripts for which they may have a conflict of interest. The editors and reviewers of this article have no conflicts of interest.

Received for publication April 30, 2020; revisions received April 30, 2020; accepted for publication May 4, 2020; available ahead of print May 14, 2020.

Address for reprints: Pavan Atluri, MD, Division of Cardiovascular Surgery, Hospital of the University of Pennsylvania, 3400 Spruce St, 6 Silverstein Pavilion, Philadelphia, PA (E-mail: Pavan.Atluri@uphs.upenn.edu).

J Thorac Cardiovasc Surg 2020;160:727

$0022-5223 / \$ 36.00$

Copyright (c) 2020 by The American Association for Thoracic Surgery

https://doi.org/10.1016/j.jtcvs.2020.05.021
}

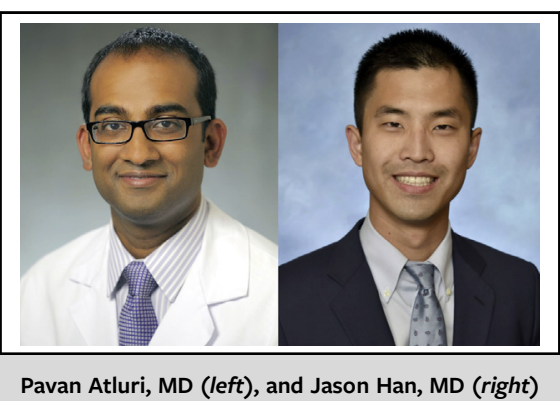

CENTRAL MESSAGE

The COVID-19 pandemic has

affected every aspect of cardiothoracic surgery and society at large, requiring collaboration and leadership to move forward.

know, is essential to coordinating our next several steps, which will be vital to the future of our specialty. First, we need to demonstrate that quality of care in cardiothoracic surgery has remained steadfast. Our operative strategy must consider the residual risk of the virus, both to those who have recovered from it and are still at risk of becoming infected, as well as concerns related to resources, staffing, and training, as all of these factors will ultimately influence outcome. Second, what will be the nature of cardiac surgical demand after the pandemic? Will these patients be sicker? How much regional variation will we observe? Of course, these answers are elusive insofar as our understanding of and armamentarium against COVID-19 evolves on a dayto-day basis.

For the time being, we have to keep on asking, measuring, and learning. Surgeons have an important role to play in this multidisciplinary endeavor-the continuum across primary care, cardiology, perioperative, and critical care that all go into saving a life. Our tireless zeal for research is needed more than ever, to identify and overcome bottlenecks, and to ensure quality, which will dispel fears and instill confidence among the public as we take small steps toward restoring normalcy. More than 40 days in, it is far too early to know the trajectory of this pandemic. As Winston Churchill once said, "Now this is not the end. It is not even the beginning of the end. But it is, perhaps, the end of the beginning." However, as Dr Craig Smith told his staff on April 3, 2020, trudge forward, as "This is our performance, our curtain call... Years of education and training, long hours, emotional stress, and social-life sacrifices are rewarded by the simple gratitude of patients, one at a time." 6 


\section{References}

1. Snowden FM. Epidemics and Society: From the Black Death to the Present. New Haven, CT: Yale University Press; 2020.

2. Emanuel EJ, Persad G, Upshur R, Thome B, Parker M, Glickman A, et al. Fair allocation of scarce medical resources in the time of COVID-19. N Engl J Med. March 23, 2020 [Epub ahead of print].

3. Hassan A, Arora RC, Adams C, Bouchard D, Cook R, Gunning D, et al. Cardiac surgery in Canada during the COVID-19 pandemic: a guidance statement from the Canadian Society of Cardiac Surgeons. Can J Cardiol. 2020; 36:952-5.
4. Haft JW, Atluri P, Alawadi G, Engelman D, Grant MC, Hassan A, et al. Adult cardiac surgery during the COVID-19 pandemic: a tiered patient triage guidance statement. J Thorac Cardiovasc Surg. April 10, 2020 [Epub ahead of print].

5. Bakaeen FG, Gillinov AM, Rosell EE, Chikwe J, Moon MR, Adams DH, et al. Cardiac surgery and the coronavirus disease 2019 pandemic: what we know, what we don't know, and what we need to do. J Thorac Cardiovasc Surg. 2020; 160:722-6.

6. Smith C. COVID-19 Update from Dr. Smith. Columbia University Department of Surgery; April 3, 2020. Available at: columbiasurgery.org/news/covid-19-updatedr-smith-4320. Accessed May 1, 2020.
See Article page 722.

\section{Commentary: Business as usual: A thing of the past}

\author{
Tomer Z. Karas, MD, and Kevin D. Accola, MD
}

The manuscript prepared by Bakaeen and other notable colleagues from respected institutions throughout our country is timely and thought-provoking. ${ }^{1}$ It emphasizes the important historic role cardiothoracic surgeons have had in times of crisis. Now, during the unprecedented and unpredictable circumstances of the coronavirus 2019 (COVID-19) pandemic, we must be prepared to lead again.

Much of what we have learned has been acquired "on the fly." The impact of rapid medical publication and even social media is apparent; the immediacy of information has been crucial, but misinformation and even disinformation abound. Certainly, collaboration with, and guidance from, our global colleagues has been beneficial and signifies the importance of American Association for Thoracic Surgery's and Society of Thoracic Surgeons' international efforts.

The legacy of the pandemic is yet to be determined. From a purely biologic perspective, infection may result in countless deaths and a variety of other morbidities from

From the Cardiovascular Institute, AdventHealth Orlando, Orlando, Fla. Disclosures: The authors reported no conflicts of interest.

The Journal policy requires editors and reviewers to disclose conflicts of interest and to decline handling or reviewing manuscripts for which they may have a conflict of interest. The editors and reviewers of this article have no conflicts of interest.

Received for publication May 12, 2020; revisions received May 12, 2020; accepted for publication May 12, 2020; available ahead of print May 30, 2020.

Address for reprints: Kevin D. Accola, MD, Cardiovascular Institute, AdventHealth Orlando, 217 Hillcrest St, Orlando, FL 32801 (E-mail: Kevin.accola@ AdventHealth.com).

J Thorac Cardiovasc Surg 2020;160:728-9

0022-5223/\$36.00

Copyright (c) 2020 by The American Association for Thoracic Surgery

https://doi.org/10.1016/j.jtcvs.2020.05.057
Check for updates

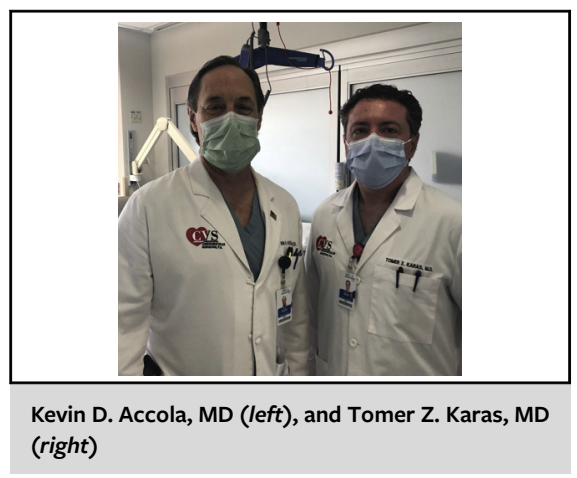

CENTRAL MESSAGE

A modern global crisis places

cardiothoracic surgeons on the

forefront of leadership and in-

genuity with the challenge of

defining a new normalcy for an

unprecedented era in health

care.

cardiomyopathies, to chronic pulmonary disease, vasculopathies, and other yet-to-be determined illnesses. The authors note interesting phenomena unrelated to the virus itself: the precipitous decline in the incidence of cardiac emergencies as well as a deliberate case volume reduction at most institutions. The former is a result of fear within the community and the latter is a result of necessary health care rationing at a time in which resources are scarce. Both of these reactions are arguably very reasonable, given uncertainties in both how well hospitalized patients can be protected in the current environment and how reliable our health care infrastructure is under this unprecedented burden. Regardless, it is clear that patients have had, and 